\title{
Short-term efficacy of joint and soft tissue injections for musculoskeletal pain: An interventional cohort study
}

\author{
Eklem ve yumuşak doku enjeksiyonlarının muskuloskeletal ağrı üzerine kısa dönem \\ etkinliği: girişimsel kohort çalışması
}

Hamza SUCUOĞLU,' Sibel SÜZEN ÖZBAYRAK, ${ }^{2}$ MUrat ULUDAĞ, ${ }^{3}$ Şansın TÜZÜN

\begin{abstract}
Summary
Objectives: Musculoskeletal injections (MIs) are frequently used in conservative treatment-resistant cases. Joint or soft tissue (ST) corticosteroid (CS) or local anesthetic (LA) injections can be used to relieve musculoskeletal pain. Assessed in the present study was the short-term efficacy of Mls for pain relief, as was the relative efficacy of injections in various joint and ST sites.

Methods: An interventional prospective cohort design was employed in the present study. Joint or ST injections for musculoskeletal pathologies were performed in patients over 18 years of age who were resistant to conservative treatment methods. Pain during rest and activity were evaluated using visual analog scale (VAS) by different clinicians prior to treatment and 3 weeks after. At the end of the study, efficacy at 7 injection sites (myofascial trigger points, shoulder, knee, lateral epicondyle, plantar fascia, lumbar, and coccyx regions) was analyzed.
\end{abstract}

Results: Injections were administered to 225 of the 250 patients included. A total of 128 patients, of whom 94 were female, completed the study. Resting VAS values before and after treatment were $4.35 \pm 1.49$ and $1.63 \pm 1.74$, respectively. Activity VAS values before and after treatment were $8.41 \pm 1.33$ and $4.04 \pm 2.37$, respectively. Changes in resting and activity VAS values were significant $(p<0.005)$. Significant reductions in pain were observed at all injection sites following treatment.

Conclusion: Significant improvement in pain scores was observed 3 weeks after injections among all injection sites. LA or CS injections can be used safely and efficiently for pain relief over short time periods.

Keywords: Injection; joint; soft tissue; pain; rehabilitation.

\section{Özet}

Amaç: Muskuloskeletal enjeksiyonlar konservatif tedaviye dirençli olgularda sıklıkla kullanılmaktadır. Eklem veya yumuşak doku (YD), kortikosteroid (KS) veya lokal anestezik (LA) enjeksiyonları kas-iskelet ağrısını gidermek için kullanılabilir. Bu çalışmada, Mi'ların farklı eklem ve YD bölgelerinde ağıı tedavisi üzerine kısa dönem etkinliği değerlendirildi.

Gereç ve Yöntem: Bu çalışma, girişimsel prospektif kohort olarak tasarlandı. Konservatif tedavi yöntemlerine dirençli 18 yaş üzeri hastalara, kas iskelet patolojilerine göre eklem ve YD enjeksiyonları yapılmıştır. Hastaların, istirahat ve aktivite sırasındaki ağrıları başka bir doktor tarafından visual analog skalası (VAS) ile tedavi öncesi, tedavi sonrası 3. haftada değerlendirildi. Çalışmanın sonunda, yedi enjeksiyon bölgesine göre (miyofasyal tetik noktalar, omuz, diz, lateral epikondil, plantar fasya, lomber ve kuyruk sokumu) analiz yapıldı.

Bulgular: Enjeksiyon çalışmaya dahil edilen 250 hastanın 225'ine uygulandı. 94'ü kadın, toplam 128 hasta çalışmayı tamamladı. Tedavi öncesi ve sonrası istirahat VAS değerleri sırasıyla $4.35 \pm 1,49$ ve $1,74 \pm 1,63$ idi. Tedavi öncesi ve sonrası aktivite VAS değerleri sırasıyla $8.41 \pm 1.33$ ve $4.04 \pm 2,37$ idi. İstirahat ve aktivite VAS değerlerinde değişiklikler anlamlıydı $(p<0.05)$. Ayrıca ağrıdaki düzelme tedavi sonrası tüm enjeksiyon bölgelerinde gözlenmiştir $(p<0.05)$.

Sonuç: Muskuloskeletal enjeksiyonlar ile tüm enjeksiyon bölgelerinde 3 haftalık dönemde ağrı skorlarında anlamlı düzelme gözlendi. LA veya KS enjeksiyonları eklem ve YD'larda, kısa dönemde ağrı tedavisinde güvenli ve etkin bir şekilde kullanılabilir.

\section{'Department of Physical Medicine and Rehabilitation, Silopi State Hospital, Şırnak, Turkey \\ 2Department of Physical Medicine and Rehabilitation, Haydarpaşa Numune Training and Research Hospital, isstanbul, Turkey \\ ${ }^{3}$ Department of Physical Medicine and Rehabilitation, İstanbul University Cerrahpaşa Faculty of Medicine, İstanbul, Turkey \\ Submitted: 03.04.2015 Accepted after revision: 09.11.2015}

Correspondence: Dr. Hamza Sucuoğlu. Cerrahpaşa Tıp Fakültesi, Fiziksel Tıp ve Rehabilitasyon Anabilim Dalı, Fatih, İstanbul, Turkey. 


\section{Introduction}

Musculoskeletal diseases are commonly encountered in physiatry practice, and musculoskeletal pain is the main complaint in hospital admissions. Musculoskeletal injections (MI) are used frequently in conservative treatment-resistant cases. Joint (intraarticular), soft tissue (ST) corticosteroid (CS), or local anesthetic (LA) injections can be used to relieve musculoskeletal pain. ${ }^{[1]}$

As with any procedure, success depends on obtaining the correct diagnosis, performing the correct procedure, and using the most appropriate pharma-

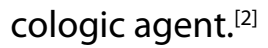

Intra-articular (IA) and ST injection procedures are safe when used by experienced clinicians in appropriately selected patients. ${ }^{[1]}$ Physical medicine and rehabilitation (PMR) doctors are particularly interested, and experienced, in the use of musculoskeletal injections (MI) in our country, with injections administered frequently and safely to patients.

The most common indications for therapeutic Ml are inflammatory and non-inflammatory arthritis and ST pathologies (myofascial trigger point, bursitis, tendinitis, epicondylitis, etc..). ${ }^{[2]}$ In general, injections can be administered within the joint (intra-articular), the joint space (peri-articular), or within specific ST structures. Injections can be used to definitively treat a condition, to provide a pain-free window for rehabilitative therapy (that is ultimately curative), or to provide episodic pain and symptom relief. ${ }^{[2]}$

The aim of this study was to assess the short-term efficacy of $\mathrm{Ml}$ for pain relief. Our primary purpose was to determine whether patients experienced improvement in pain parameters after joint and soft tissue injections. The secondary outcome was to assess the relative extent of pain relief according to different joint and ST injection sites. A final goal was to define the optimal types and frequencies of injections that should be applied to different musculoskeletal pain regions.

\section{Materials and Methods}

\section{Study design and participants}

This study used an interventional prospective cohort design. Participants were recruited between January
2014 and November 2014 from the PMR outpatient clinic at Sirnak, Turkey.

Patients were eligible for the study if they had received an injection for musculoskeletal pain, in the procedural practice, during the time period delineated above.

The inclusion criteria were: age $>18$ years, definite diagnosis of a musculoskeletal disease, and receipt of conservative treatment (paracetamol, nonsteroidal anti-inflammatory drugs [NSAIDs], exercise, hot and cold application, resting, and splinting) 2 weeks previously with an inadequate response.

The exclusion criteria were CS injections during the previous 3 months, polyneuropathy, previous total knee-shoulder replacement, infection in the site of injection, the presence of coagulopathy or use of anti-coagulation drugs, and known hypersensitive reactions to any medications contained in the injections.

The study was conducted in accordance with the Declaration of Helsinki, and all subjects provided written informed consent. The ethics committee approval was obtained for the study.

\section{Evaluation of patients}

After demographic characteristics (age and gender) were recorded, patients were evaluated before, and 3 weeks after, injection by a doctor independent of the study. Visual analog scales (VAS) were used to assess pain at rest and during activity. At each visit, patients rated their current pain intensity on a VAS ranging from 0 (no pain) to 10 (maximum pain) $\mathrm{cm}$. In patients with coccygodynia, VAS values of pain during activity were taken as a proxy of pain during sitting.

\section{Injection techniques and pharmacotherapy} Mls are safe and comfortable treatments if applied using an appropriate technique. The injection techniques used in this study were selected according to the injection site and diagnosis. For example, IA injections were used for adhesive capsulitis, whereas subacromial injections were preferred for subacromial impingement syndrome. Table $1 \mathrm{a}$ lists the injection techniques used according to musculoskeletal site. The no-touch technique, before and after in- 
Table 1a. Injection technique according to the injection sites

\begin{tabular}{lll}
$\begin{array}{l}\text { Injection } \\
\text { sites }\end{array}$ & $\begin{array}{l}\text { Injection } \\
\text { place and } \\
\text { types }\end{array}$ & Injection techniques* \\
\hline
\end{tabular}

3 to 6 sterile acupuncture needles $(0.25 \times 25 \mathrm{~mm}$.) were inserted to trigger points with a few milimeters distance along the muscle. The time of needling (generally 10-20 minute) was adjusted according to the $\begin{array}{ll}\text { MTP } & \text { pulling of the needles by trigger points. Sometimes manual stimulation was done by turning the needles } \\ \text { in the opposite direction of clock. After releasing of the needles by trigger points via relaxation the muscle, }\end{array}$ the needles were removed.

Injection with local anesthetic

Piriformis injection

Intra$\operatorname{articular}^{1}$

Subacromial $^{1}$

Indirect block of

Shoulder suprascapular nerve ${ }^{2}$

Knee Intra$\operatorname{articular}^{1}$

Pes anserine Baker cyst

LE Directly ${ }^{14}$

PF Directly Injection

Lumbar of lumbar pvm $^{25}$

Episacral lipoma (Copeman nodule) injection $^{26}$

Injection around

Coccyx

the coccyx

21 or 22 gauge needle was inserted into most sensitive region. By confirmation of the trigger point by detecting radiation of the pain by pressure or feeling of stiffness or jerk of the muscle during injection, a solution of 1 cc of lidocaine was injected after negative aspiration.

With the patient in prone position, the most sensitive region of piriformis muscle were determined and 22 gauge $10 \mathrm{~cm}$ spinal needle was inserted to this region. After feeling stiffness or jerk of muscle during injection, solution was injected after negative aspiration.

Start with the patient sitting on the examination table at a height that is comfortable for you. We often use a posterior approach for shoulder injection. Specifically, palpate just the scapular spine and move laterally until you feel a space or indentation. Next locate the coracoid process anteriorly. When inserting the needle, direct it toward the tip of the coracoid process.

The needle was inserted in the space posterolateral to the acromion process. The needle should be inserted parallel to the ground and at a depth of approximately $3 \mathrm{~cm}$.

The technique consists of injecting anesthetic in supraspinatus fossa of affected shoulder, with the patient sitting down and upper limbs pending beside the body. The health care provider must palpate anatomical parameters like clavicle, acromioclavicular articulation, acromion, scapula spine and coracoid process. the needle introduction site is medial to vertex obtained from two imaginary lines traced over upper edge of clavicle and anterior edge of scapula spine, laterally to the coracoid process. The needle is advanced in craniocaudal direction, perpendicular to skin, crossing the trapezium and supraspinatus muscles, until it reaches the supraspinatus fossa ( 3 to $4 \mathrm{~cm}$ ), adjacent to coracoid process basis where the nerve is located.

With the patient lying supine, slight flexion were given to patients' knee by putting a small pillow under the knee. Medial approach for injection was preferred. By palpation the patella, upper, lower and lateral borders were determined. The needle were inserted from medial aspect of the patella by feeling a small cleft underneath the patella to 3 o'clock direction. Aspiration was done if effusion was presentand the solution was injected.

The most sensitive point of the pes anserine region were detected. The injection was done directly to this point.

After detecting posterior swelling at the medial aspect of the joint where the semimembranous and medial head of the gastrocnemius intersect between 2 fingers, 21 gauge $10 \mathrm{ml}$ needle were inserted into it by negative pressure. After aspiration of the effusion, the solution were injected.

22 gauge $5 \mathrm{ml}$ needle were inserted to lateral epicondyle region, after negative aspiration the solution was injected radially.

With the patient lying down, 21 gauge $5 \mathrm{ml}$ needle were inserted to the plantar fascia from the medial side of the heel directly, after negative aspiration the solution were injecterd.

Paravertebral injection to most sensitive 4-6 muscle points with 21 gauge $5 \mathrm{ml}$ needle were done after negative aspiration.

After stabilizing the nodule with 2 finger, 21 gauge needle were inserted into it and multiple puncture technique were used ( 6 to 8 punctures of the fibrous capsule of the nodule). After negative aspiration, a solution composed of local anesthetic and corticosteroid combination were used.

with mani-

pulation $^{30}$

The soft tisues around the sides and tip of the coccyx were infiltrated but no atempt was made to enter the sacrococygeal joint. The manipulation was performed, with the patient in the left lateral positon, using the index finger per rectum and the thumb overlying the coccyx. The coccyx was repeatedly flexed and extended over a period of aproximately $30 \mathrm{~s}$ taking due care of the rectal mucosa.

MTP: Myofascial trigger point; LE: Lateral epicondyle; PF: Plantar fascia , pvm: paravertebral muscle; *No-touch technique before and after injection was used for skin anti sepsis to all patients 
Table 1b. Steps for the No-touch technique

1. The patient was positioned on the examination table at a height comfortable for injection

2. The anatomic landmarks were identified and the injection site with a pen was marked. Also, by pressing gently with using the tip of the pen, an indentation at the injection point was made. This would be the guide if the pen mark is erased by the antiseptic

3. The site with the antiseptic cleaned. isopropyl alcohol ve povidone iodine [Betadine] together were used for thispurpose

4. The injected area with an adhesive bandage was covered

The disinfected area didn't touched. Gloves worn as a universal precaution. However, sterile gloves was unnecessary because this was a no-touch technique.

jection, was used for skin anti-sepsis in all patients (Table 1b).

MI typically involves a combination of $L A$, which provides immediate analgesia and confirmation of accurate injection placement, and CS, which provides more prolonged analgesia. The CS used in our clinic for joint and soft tissue injection is betamethasone sodium phosphate/dipropionate (Diprospan ${ }^{\circledR}$ ). The LA frequently used for joint and soft tissue injections is lidocaine (Jetokain ${ }^{\oplus}$ ).

LA injection was not used in patients with known hypersensitivity to this agent, or if the allergic status to this medication was unknown. Dry needling with sterile acupuncture needles $(0.25 \times 25 \mathrm{~mm})$ was used for myofascial trigger points (MTP) in such patients. CS injection (1 $\mathrm{ml}$ betamethasone) alone, without local anesthetics, was used for IA and ST injections. Furthermore, hyaluronic acid (HA) injection $(60 \mathrm{mg} / 4$ $\mathrm{ml}$ hyaluronic acid sodium 1.5\%) was used for knee osteoarthritis patients. Suprascapular nerve blockage with LA (5 $\mathrm{ml}$ lidocaine $2 \%$ ), via indirect methods, was employed for patients with severe shoulder pain. For all other patients, LA and CS were used in combination.

\section{Statistical analysis}

All statistical analyses were performed using the SPSS for Windows software package (ver. 22.0; SPSS Inc., Chicago, IL, USA). All data are presented as arithmetic mean \pm standard deviation (SD). The normality of data was assessed using the Shapiro-Wilk test. Independent samples t-tests were used to compare normally distributed variables, and nonparametric Mann-Whitney $U$ and Wilcoxon tests were used to compare non-normally distributed variables. The
Mann-Whitney $U$ test was also used to compare groups (between-group comparison). The Wilcoxon test was used to compare the results of tests performed before and after treatment (within-group comparison). For all analyses, a value of $p<0.05$ was considered to indicate statistical significance.

\section{Results}

Injections were performed in 225 of the 250 patients included in this study. Data from a total of 128 patients, 94 of whom were female, were analyzed at the end of the study (Table 2, Fig. 1). The mean ages of female and male patients were $44.07 \pm 14.13$ years and $46.97 \pm 15.86$ years, respectively. All patients receiving plantar fascia injection were female. The youngest patient group was those receiving coccygodynia injections; MTP patients were also relatively young. Table 2 lists the age and sex distribution of patients according to injection site.

Acupuncture needles were used in 8 patients, with LA used in 17 cases and HA in 3 others; CS alone or in conjunction with LA was used in all remaining patients (Table 3).

Table 4 lists injection types and distribution according to musculoskeletal site. There were 42 intraarticular shoulder or knee injections and 96 periarticular or ST injections.

Table 5 lists resting (rest) and activity (act) pain scores, before and after treatment and according to injection sites. Rest-VAS values before and after treatment were $4.35 \pm 1.49$ and $1.63 \pm 1.74$, respectively. Act-VAS values before and after treatment were $8.41 \pm 1.33$ and $4.04 \pm 2.37$, respectively. Changes in rest-VAS and act-VAS values were significant $(p<0.05)$. Addition- 
Table 2. The sex and age distribution according to injection site

\begin{tabular}{|c|c|c|c|c|}
\hline & & Male & Female & $\mathbf{p}$ \\
\hline \multirow[t]{2}{*}{ Total } & $\mathrm{N}$ & 34 & 94 & \\
\hline & Age (Mean \pm SD) & $46.97 \pm 15.86$ & $44.07 \pm 14.13$ & 0.324 \\
\hline \multirow[t]{2}{*}{ MTP } & $\mathrm{N}$ & 6 & 19 & \\
\hline & Age (Mean \pm SD) & $47.33 \pm 19.57$ & $31.53 \pm 10.31$ & 0.080 \\
\hline \multirow[t]{2}{*}{ Shoulder } & $\mathrm{N}$ & 6 & 18 & \\
\hline & Age (Mean \pm SD) & $50.00 \pm 8.46$ & $50.78 \pm 11.30$ & 0.879 \\
\hline \multirow[t]{2}{*}{ Knee } & $\mathrm{N}$ & 12 & 19 & \\
\hline & Age (Mean \pm SD) & $55.17 \pm 15.56$ & $55.79 \pm 13.66$ & 0.908 \\
\hline \multirow[t]{2}{*}{ LE } & $\mathrm{N}$ & 2 & 12 & \\
\hline & Age (Mean \pm SD) & $38.00 \pm 1.41$ & $39.42 \pm 6.58$ & 0.774 \\
\hline \multirow[t]{2}{*}{ PF } & $\mathrm{N}$ & 0 & 10 & \\
\hline & Age (Mean \pm SD) & & $46.70 \pm 13.57$ & - \\
\hline \multirow[t]{2}{*}{ Lumbar } & $\mathrm{N}$ & 5 & 11 & \\
\hline & Age (Mean \pm SD) & $39.40 \pm 12.79$ & $41.45 \pm 10.27$ & 0.735 \\
\hline \multirow[t]{2}{*}{ Coccyx } & $\mathrm{N}$ & 3 & 5 & \\
\hline & Age (Mean $\pm S D)$ & $26.00 \pm 6.08$ & $34.80 \pm 13.18$ & 0.230 \\
\hline
\end{tabular}

MTP: Myofascial trigger point; LE: Lateral epicondyle; PF: Plantar fascia; SD: Standart deviation; N: Patient number

ally, significant improvement in pain was detected at all injection sites after treatment $(p<0.05)$.

More patients presented to our clinic with coccygodynia than expected; 13 of these patients received injections. Of these patients, only 8 completed the study.

Several side effects were observed after injections, virtually all of which were seen within 1 hour of treatment. Side effects included syncope $(n=3)$, hypotension, sweating, nausea and tachycardia $(n=5)$, and short-term faintness $(n=8)$. Severe systemic toxicity, such as convulsion, anaphylaxis, or cardiac or respiratory arrest, was not observed. Complications after CS injection, such as depigmentation, adipose atrophy, infection, tendon rupture, or septic arthritis, were also not detected. Injections were discontinued in patients experiencing side effects; interventions were performed with a 12-hour follow-up in these cases.

\section{Discussion}

Musculoskeletal problems are common in physiatry practice and frequently respond to injections containing both corticosteroid and short-acting anesthetics. Patients frequently present with symptoms involving the joints and ST. ${ }^{[1]}$

Table 3. Patient number and distribution according to types and sites of injection

\begin{tabular}{|c|c|c|c|c|c|c|c|}
\hline \multirow[b]{2}{*}{ Injection types } & \multicolumn{6}{|c|}{ Injection sites } & \multirow[b]{2}{*}{ Coccyx } \\
\hline & MTP & Shoulder & Knee & LE & PF & Lumbar & \\
\hline Dry needling (n) & 8 & & & & & & \\
\hline LA (n) & 17 & & & & & & \\
\hline $\mathrm{CS}(\mathrm{n})$ & & 1 & 7 & 1 & 3 & 3 & 1 \\
\hline $\mathrm{LA}+\mathrm{CS}(\mathrm{n})$ & & 23 & 21 & 13 & 7 & 13 & 7 \\
\hline $\mathrm{HA}(\mathrm{n})$ & & & 3 & & & & \\
\hline
\end{tabular}

MTP: Myofascial trigger point; LE: Lateral epicondyle; PF: Plantar fascia; n: patient number; LA: Local anesthetics (lidocaine 2\%); CS: Corticosteroid (betamethasone 2+5mg); HA: Hyaluronic acid 


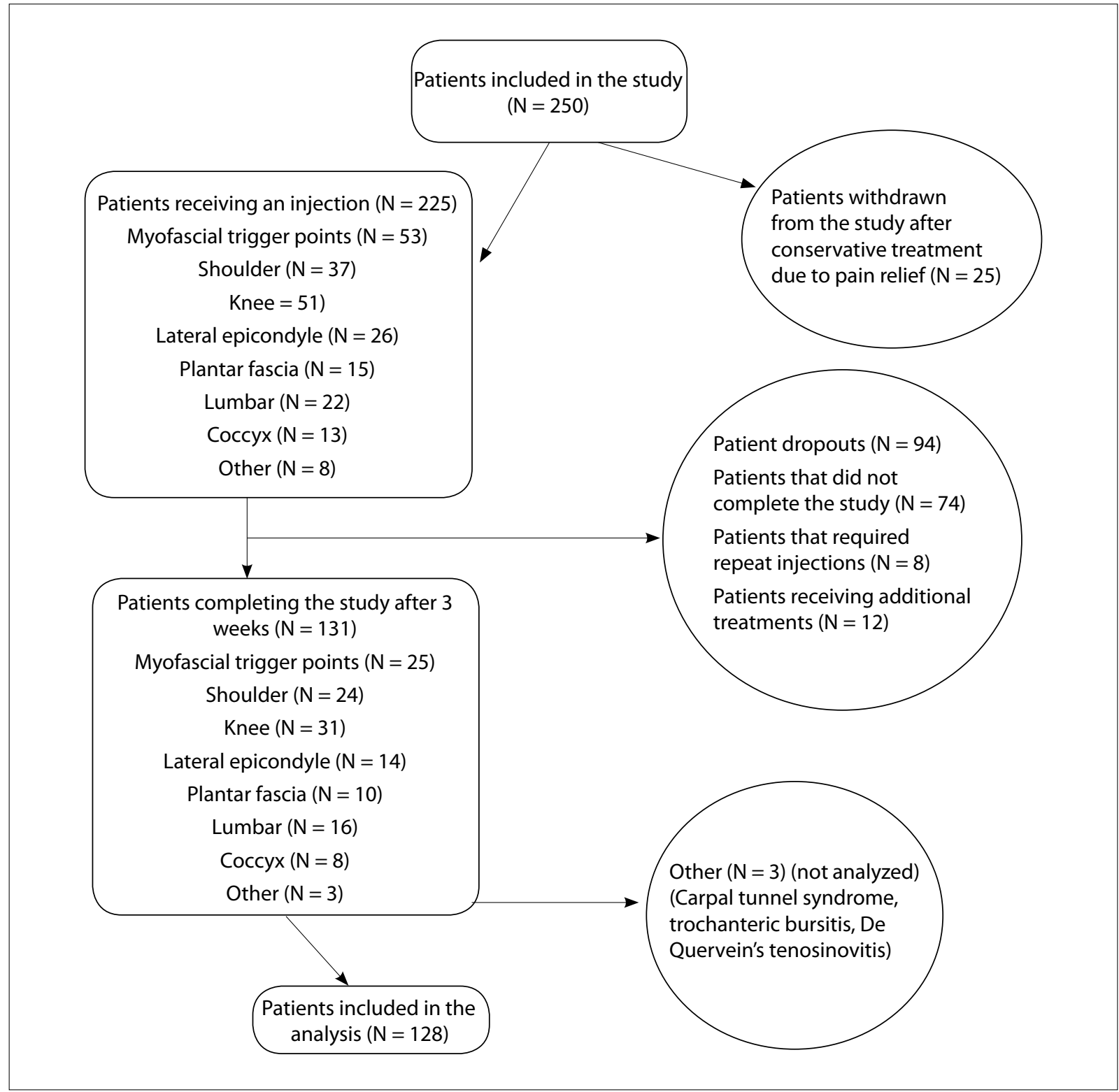

Figure 1. Distribution of patients and study flowchart

The main effects of therapeutic Ml are pain and symptom relief, and control of pain during rehabilitation. Although the short-term efficacy of $\mathrm{Ml}$ is well-known, its long-term effects are still debated. ${ }^{[2]}$ Furthermore, few studies have focused on how injections affect pain and symptom relief at different injection sites. We searched for studies on the shortterm efficacy of injections for pain relief at seven different musculoskeletal sites; significant improvements were reported at all musculoskeletal sites.

Mls are commonly performed as intra-articular or specific ST (tendon, ligament, bursa, and muscle) injections. Nerve blockage injections are also frequently administered. In this study, we performed general IA and ST injections, but used suprascapular nerve-blocking injections for several patients with shoulder pain (with appropriate indications).

For the purposes of this study, CS alone, or in combination with $L A$, were injected for the majority of IA or ST injections. ${ }^{[2]}$ Evidence generally supports the use of CS injections, ${ }^{[1,3]}$ because injected CSs decrease swelling and pain, permitting improved range of motion and thereby facilitating rehabilitation. ${ }^{[4-7]}$ We chose CS injections frequently for all regions except MTP. Triamcinolone is the preferred CS in the literature, and comparisons between types of CS indicate that triamcinolone hexacetonide is superior to betamethasone. ${ }^{[1,3]}$ Lidocaine is mid-lasting, potent, and reliable, so it is the preferred LA in the literature, and was also used in our study. ${ }^{[8]}$ We used CS and LA in 
Table 4. Injection number and distribution according to injection sites and techniques

\begin{tabular}{|c|c|c|c|c|c|c|c|c|}
\hline \multirow[b]{2}{*}{ Injection technique } & \multicolumn{8}{|c|}{ Injection site } \\
\hline & MTP & Shoulder & Knee & LE & PF & Lumbar & Coccyx & Total \\
\hline Intra-articular & & 12 & 20 & & & & & 32 \\
\hline Aspiration (intra-articular or baker cyst) & & & 10 & & & & & 10 \\
\hline Peri-articular or Soft Tissue & & & & & & & 8 & 8 \\
\hline Pes anserine bursa & & & 9 & & & & & 9 \\
\hline Subacromial bursa & & 12 & & & & & & 12 \\
\hline Suprascapular nevre block & & 4 & & & & & & 4 \\
\hline Trapezius m. & 16 & & & & & & & 14 \\
\hline Rhomboid $\mathrm{m}$. & 4 & & & & & & & 4 \\
\hline Infraspinatus m. & 2 & & & & & & & 2 \\
\hline Piriformis m. & 2 & & & & & & & 2 \\
\hline Gastrosoleus m. & 1 & & & & & & & 1 \\
\hline Lateral epicondyle & & & & 14 & & & & 14 \\
\hline Plantar fascia & & & & & 10 & & & 10 \\
\hline Lumbar pvm & & & & & & 12 & & 12 \\
\hline Copeman nodule & & & & & & 4 & & 4 \\
\hline
\end{tabular}

MTP: Myofascial trigger point; LE: Lateral epiconyle; PF: Plantar fascia; pvm: paravertebral muscle.

combination or individually and assessed the shortterm efficacy of both regimens. The effects of the different injections according to musculoskeletal site are discussed below.

The majority of the patients receiving dry needling or LA injections for MTP reported significant improvement. A previous review of seven studies noted limited evidence of dry needling on MTP, and a meta-analysis concluded that this technique is not superior to placebo. ${ }^{[9]}$ In another study, 39 elderly patients complaining of myofascial pain in the trapezius muscle were randomly divided into two groups; significant improvements in pain were observed after 4 weeks, but there was no significant difference between groups. ${ }^{[10]}$

Shoulder pain of different etiologies may respond to a single IA or subacromial CS injection. The main indications for shoulder injection are subacromial impingement syndrome, adhesive capsulitis, and rotator cuff arthropathy ${ }^{[1]}$ In our study, IA or subacromial injections were administered to 24 patients with shoulder pain due to subacromial impingement syndrome, adhesive capsulitis, or rotator cuff arthropathy; four patients received additional suprascapular nerve-blocking injections. Significant improvements in pain both at rest and during activity were detected over a short time period. Subacromial corticosteroid injections confer a marginal additional benefit over placebo, but no additional benefit over nonsteroidal anti-inflammatory drug therapy during rotator cuff disease. Concerning adhesive capsulitis, two trials suggest a possible early benefit of IA corticosteroid injections over placebo, but the data were insufficient for firm conclusions. ${ }^{[1,11]}$ IA corticosteroid injections are known to have limited effects on rotator cuff arthropathy. ${ }^{[11]}$

Knee pain is a common symptom in primary care practice. The main indications for IA knee injections are osteoarthritis and the presence of Baker's cyst or pes anserine bursitis. ${ }^{[1]}$ IA corticosteroid injections improve function and reduce swelling and pain. ${ }^{[3]}$ The onset of action is rapid (typically within 24 hours) and clinical effects last between 4 and 8 weeks. Repeated CS injections for knee osteoarthritis are safe and do not accelerate disease progression. ${ }^{[12]}$ In a Cochrane systemic review of 28 trials (1973 participants) involving IA corticosteroid injections to treat knee osteoarthritis, IA corticosteroid injections were superior to placebo and HA injections for pain relief, 
Table 5. The resting and activity pain scores before and after treatment according to injection sites

\begin{tabular}{|c|c|c|c|c|c|c|c|}
\hline & $\mathbf{N}$ & $\begin{array}{c}\text { BT-rest-VAS } \\
\text { Mean } \pm S D \\
\text { (min-max) }\end{array}$ & 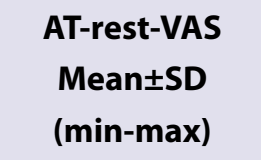 & $\mathbf{p}$ & $\begin{array}{l}\text { BT-act-VAS } \\
\text { Mean } \pm S D \\
\text { (min-max) }\end{array}$ & $\begin{array}{c}\text { AT-act-VAS } \\
\text { Mean } \pm S D \\
\text { (min-max) }\end{array}$ & $\mathbf{p}$ \\
\hline Total & 128 & $4.35 \pm 1.49(0-10)$ & $1.63 \pm 1.74(0-10)$ & $0.000^{*}$ & $8.41 \pm 1.33(3-10)$ & $4.04 \pm 2.37(0-10)$ & $0.000^{*}$ \\
\hline MTP & 25 & $5.32 \pm 1.79(2-10)$ & $2.80 \pm 2.46(0-10)$ & $0.000^{*}$ & $8.52 \pm 1.73(3-10)$ & $5.00 \pm 2.67(0-10)$ & $0.000^{*}$ \\
\hline Shoulder & 24 & $4.42 \pm 0.92(3-7)$ & $1.79 \pm 1.38(0-6)$ & $0.000^{*}$ & $8.42 \pm 1.01(7-10)$ & $4.33 \pm 2.12(2-9)$ & $0.000^{*}$ \\
\hline Knee & 31 & $4.35 \pm 1.25(1-7)$ & $1.58 \pm 1.52(0-5)$ & $0.000^{*}$ & $8.52 \pm 1.43(5-10)$ & $4.26 \pm 2.44(2-10)$ & $0.000^{*}$ \\
\hline LE & 14 & $3.57 \pm 0.75(3-5)$ & $0.29 \pm 0.46(0-1)$ & $0.001^{*}$ & $7.71 \pm 1.06(6-10)$ & $1.86 \pm 1.40(0-4)$ & $0.001 *$ \\
\hline PF & 10 & $3.50 \pm 0.85(2-5)$ & $1.30 \pm 1.41(0-3)$ & $0.007^{*}$ & $8.30 \pm 0.82(7-10)$ & $4.50 \pm 1.95(2-7)$ & $0.007^{*}$ \\
\hline Lumbar & 16 & $4.75 \pm 1.48(3-7)$ & $1.44 \pm 1.31(0-4)$ & $0.001^{*}$ & $8.69 \pm 1.40(5-10)$ & $3.44 \pm 2.25(0-8)$ & $0.001 *$ \\
\hline Coccyx & 8 & $2.75 \pm 2.12(0-7)$ & $0.88 \pm 1.35(0-3)$ & $0.026^{*}$ & $8.38 \pm 1.18(7-10)$ & $3.75 \pm 1.75(2-7)$ & $0.017^{*}$ \\
\hline
\end{tabular}

MTP: Myofascial trigger point; LE: Lateral epicondyle; PF: Plantar fascia; SD: Standart deviation; N: patient number; min: minimum value; max: maximum value; BT: Before treatment; AT: After treatment; rest: resting; act: activity; VAS: visual analouge scale; ${ }^{*} p<0,05$.

reduced patient global assessment pain scores at 1 week, and reduced pain for 2-3 weeks. ${ }^{[3]}$ In another study, the effects of IA CS and LA for knee osteoarthritis were evaluated. Injections decreased pain sensitivity in both the knee and the surrounding muscles; the effects were immediate and sustained for at least 2 weeks. ${ }^{[13]}$ We observed significant improvements in pain after IA, pes anserine bursa, and Baker's cyst injections, although several patients required a second injection and therefore were excluded from the study.

With regard to lateral epicondylitis, Mandiroglu et al. ${ }^{[14]}$ reported that physical therapy is slightly superior to the other treatment modalities, among which there was no difference in effectiveness. However, because physical therapy is more expensive than NSAID and CS injections, and is more time-consuming and requires more specialist equipment, its use should be based on the particular situation of each patient and therapy center. ${ }^{[14]}$. A study comparing the effectiveness of physical therapy and CS injections, reported that CSs are superior in the short-term but physical therapy is superior in the long-term. ${ }^{[15,16]}$ With regard to tennis elbow, Tonks et al. ${ }^{[17]}$ assessed the relative merits of a 'watch and wait' policy, physiotherapy alone, steroid injection therapy alone, and combined physiotherapy and steroid injection therapy, using a prospective randomized controlled trial design. After 7 weeks, patients who received steroid injections had significantly superior outcomes on all measures at follow-up. No significant effect of physiotherapy, or interaction between physiotherapy and injection, was found. Based on these results, the authors advocated steroid injection alone as the first-line treatment for patients presenting with tennis elbow who require a rapid return to their daily activities. In contrast, Newcomer et al. ${ }^{[18]}$ advised that rehabilitation should be the first choice, based on the results of their study comparing the effects of rehabilitation programs and CS injections. A review by Boisaubert (2004) ${ }^{[19]}$ concluded that CS injection was the optimal short-term treatment option. However, the beneficial effects persisted only for a short time, and the longterm outcome may be poor. In the long-term, physiotherapy (pulsed ultrasound, deep friction massage, and exercise programs) was the best option, but outcomes were not significantly different from those associated with the 'wait-and-see' approach. Insufficient evidence is available to support or refute other treatment options. The results of our study indicate that CS injections for lateral epicondylitis offer pain relief that is effective for 3 weeks and can be reliably used as the first-choice treatment option.

Plantar fasciitis is the most common cause of heel pain in adults. CS injections for plantar fasciitis are known to be an effective choice of treatment. ${ }^{[20-24]}$ In a study by Li et al., ${ }^{[20]}$ treatment with steroid injections had- a significant effect only at the 1-month, and not the 6- or 12-month, follow-ups. In a randomized controlled study involving 106 patients, Crawford et al. ${ }^{[21]}$ reported that CS injections were superior to placebo at 1 month, but not at subse- 
quent follow-up assessments. In another randomized study, Ball et al. ${ }^{[22]}$ reported that CS injection had short- and medium-term benefits in a study involving 65 patients with plantar fasciitis. We observed a significant improvement in pain in 10 patients with plantar fasciitis after CS injections.

We administered intramuscular injections to the lumbar paravertebral points of patients diagnosed with lumbar facet syndrome, disc hernias, or nonspecific mechanical back pain. All patients exhibited significant improvement in pain scores. Riberio et al. ${ }^{[25]}$ used a similar paravertebral muscle injection technique for patients with back pain. In their study, 60 subjects with a diagnosis of facet joint syndrome were randomized into two groups: one group was administered IA CS injections into six lumbar facet joints; while the control group was administered intramuscular CS injections into six lumbar paravertebral points. Both treatments were found to be effective, with a slightly greater improvement with IA vs. intramuscular CS injections.

Another reason for injection in patients with back pain is episacral lipomas, which is a significant but treatable cause of acute and chronic low back pain. Physical therapy and injections are frequently used to treat it. ${ }^{[26]}$ Erdem et al. ${ }^{[26]}$ found that back pain due to episacral lipomas was relieved with a combination of local anesthetic and steroid injections using the multiple needling method. We also achieved good results, over a short time period, in patients with episacral lipomas.

Coccygodynia is a painful syndrome affecting the coccygeal region. We encountered more patients with coccygodynia than expected, probably due to two reasons. First, patients may believe that the majority of their back pain is due to coccygodynia and therefore tend to visit bonesetters for manipulation. The second reason may be due to the low socio-economic status, adverse working conditions, and commensurately frequent falls of women in the village from which the study participants were drawn. For the majority of patients with coccygodynia, conservative therapy appears to play a vital role in its management. Principal methods of pain reduction include analgesic use, limitation of sitting, use of ring-shaped pillows, and physiotherapy. ${ }^{[27,28]}$
In resistant cases that fail to respond to conservative treatment, intrarectal manipulation of the lower coccygeal segment can be used, occasionally with massage of the coccygeal muscles, and LA with CS injections. ${ }^{[27,29]}$ We administered injections into the coccygeal region with rectal manipulation in cases resistant to conservative treatment and observed consistent reductions in pain scores, similar to the findings of previous studies. A study by Dalbayrak et al. ${ }^{[27]}$ provides evidence that local CS injection is an effective method of treatment for patients with coccygodynia characterized by forward curvature and an absence of angulation. A 5-year prospective trial performed by Wray et al. ${ }^{[30]}$ concluded that physiotherapy treatment was of little help, but $59 \%$ of patients responded to local injections of CS and LA. Injection with manipulation was even more successful, curing approximately $85 \%$ of patients.

The majority of the side effects encountered (syncope, hypotension, short-term feeling of faintness, etc.) were due to psychogenic factors or the direct, systemic effects of LA. Local toxic effects (depigmentation, adipose atrophy, tendon rupture, etc.) of CS or LA agents were not observed in any patient.

The limitations of this study include the lack of a control group, relatively short follow-up and the small number of patients receiving injections in certain sites. Therefore, the results should be interpreted with these limitations taken into account.

\section{Conclusions}

We observed a significant improvement in pain scores 3 weeks after injections in all patients. LA or CS injections can be used safely and efficiently to provide pain relief for a short period of time. Furthermore, the success of injections can be improved by using correct techniques in appropriate patients. MI can be used successfully in patients resistant to noninterventional treatment. Because $\mathrm{Ml}$ is inexpensive, takes less time, and does not require a large amount of equipment, it can be used as a first-choice treatment.

Conflict-of-interest issues regarding the authorship or article: None declared.

Peer-rewiew: Externally peer-reviewed. 


\section{References}

1. Wittich CM, Ficalora RD, Mason TG, Beckman TJ. Musculoskeletal injection. Mayo Clin Proc 2009;84(9):831-7. CrossRef

2. Stephens MB, Beutler Al, O'Connor FG. Musculoskeletal injections: a review of the evidence. Am Fam Physician 2008;78(8):971-6.

3. Bellamy N, Campbell J, Robinson V, Gee T, Bourne R, Wells $\mathrm{G}$. Intraarticular corticosteroid for treatment of osteoarthritis of the knee. Cochrane Database Syst Rev 2006;(2):CD005328. CrossRef

4. Visnes $H$, Bahr R. The evolution of eccentric training as treatment for patellar tendinopathy (jumper's knee): a critical review of exercise programmes. Br J Sports Med 2007;41(4):217-23. CrossRef

5. Wilson JJ, Best TM. Common overuse tendon problems: A review and recommendations for treatment. Am Fam Physician 2005;72(5):811-8.

6. Blair B, Rokito AS, Cuomo F, Jarolem K, Zuckerman JD. Efficacy of injections of corticosteroids for subacromial impingement syndrome. J Bone Joint Surg Am 1996;78(11):1685-9.

7. Hay EM, Thomas E, Paterson SM, Dziedzic K, Croft PR. A pragmatic randomised controlled trial of local corticosteroid injection and physiotherapy for the treatment of new episodes of unilateral shoulder pain in primary care. Ann Rheum Dis 2003;62(5):394-9. CrossRef

8. Berde CB, Strichartz GR. Local anesthetics: Anesthesia. In: Miller RD, editor. 5th ed. Churchill Livingstone; Phileldelphia: 2000. s. 491-521.

9. Tough EA, White AR, Cummings TM, Richards SH, Campbell JL. Acupuncture and dry needling in the management of myofascial trigger point pain: a systematic review and meta-analysis of randomised controlled trials. Eur J Pain 2009;13(1):3-10. CrossRef

10. $\mathrm{Ga} \mathrm{H}$, Choi JH, Park $\mathrm{CH}$, Yoon HJ. Acupuncture needling versus lidocaine injection of trigger points in myofascial pain syndrome in elderly patients--a randomised trial. Acupunct Med 2007;25(4):130-6. CrossRef

11. Buchbinder R1, Green S, Youd JM. Corticosteroid injections for shoulder pain. Cochrane Database Syst Rev 2003;(1):CD004016.

12. Arroll B, Goodyear-Smith F. Corticosteroid injections for osteoarthritis of the knee: meta-analysis. BMJ 2004;328(7444):869. CrossRef

13. Jørgensen TS, Graven-Nielsen T, Ellegaard K, Danneskiold-Samsøe B, Bliddal H, Henriksen M. Intra-Articular Analgesia and Steroid Reduce Pain Sensitivity in Knee OA Patients: An Interventional Cohort Study. Pain Res Treat 2014;2014:710490. CrossRef

14. Mandıroglu S, Bal A, Gurcay E, Cakci A. Comparison of the effects of non-steroidal anti-inflammatory drugs, steroid injection and physical therapy in lateral epicondylitis. Turk J Phys Med Rehab 2007;53:104-7.

15. Smidt N, van der Windt DA, Assendelft WJ, Devillé WL,
Korthals-de Bos IB, Bouter LM. Corticosteroid injections, physiotherapy, or a wait-and-see policy for lateral epicondylitis: a randomised controlled trial. Lancet 2002;359(9307):657-62. CrossRef

16. Bisset L, Beller E, Jull G, Brooks P, Darnell R, Vicenzino B. Mobilisation with movement and exercise, corticosteroid injection, or wait and see for tennis elbow: randomised trial. BMJ 2006;333(7575):939. CrossRef

17. Tonks JH, Pai SK, Murali SR. Steroid injection therapy is the best conservative treatment for lateral epicondylitis: a prospective randomised controlled trial. Int J Clin Pract 2007;61(2):240-6. CrossRef

18. Newcomer KL, Laskowski ER, Idank DM, McLean TJ, Egan KS. Corticosteroid injection in early treatment of lateral epicondylitis. Clin J Sport Med 2001;11(4):214-22. CrossRef

19. Boisaubert B, Brousse C, Zaoui A, Montigny JP. Nonsurgical treatment of tennis elbow. [Article in French] Ann Readapt Med Phys 2004;47(6):346-55. [Abstract] crossRef

20. Li S, Shen T, Liang Y, Zhang Y, Bai B. Miniscalpel-Needle versus Steroid Injection for Plantar Fasciitis: A Randomized Controlled Trial with a 12-Month Follow-Up. Evid Based Complement Alternat Med 2014;2014:164714. CrossRef

21. Crawford F, Atkins D, Young P, Edwards J. Steroid injection for heel pain: evidence of short-term effectiveness. A randomized controlled trial. Rheumatology (Oxford) 1999;38(10):974-7. crossRef

22. Ball EM, McKeeman HM, Patterson C, Burns J, Yau WH, Moore $\mathrm{OA}$, et al. Steroid injection for inferior heel pain: a randomised controlled trial. Ann Rheum Dis 2013;72(6):996-1002. CrossRef

23. Kamel $M$, Kotob H. High frequency ultrasonographic findings in plantar fasciitis and assessment of local steroid injection. J Rheumatol 2000;27(9):2139-41.

24. Tsai WC, Wang CL, Tang FT, Hsu TC, Hsu KH, Wong MK. Treatment of proximal plantar fasciitis with ultrasound-guided steroid injection. Arch Phys Med Rehabil 2000;81(10):141621. CrossRef

25. Ribeiro LH, Furtado RN, Konai MS, Andreo AB, Rosenfeld A, Natour J. Effect of facet joint injection versus systemic steroids in low back pain: a randomized controlled trial. Spine (Phila Pa 1976) 2013;38(23):1995-2002. crossRef

26. Erdem HR, Nacır B, Özeri Z, Karagöz A. Episacral lipoma: a treatable cause of low back pain. [Article in Turkish] Agri 2013;25(2):83-6. CrossRef

27. Dalbayrak S, Yaman O, Yilmaz T, Yilmaz M. Treatment principles for coccygodynia. Turk Neurosurg 2014;24(4):532-7.

28. Fogel GR, Cunningham PY 3rd, Esses SI. Coccygodynia: evaluation and management. J Am Acad Orthop Surg 2004;12(1):49-54. CrossRef

29. Porter KM, Khan MAA, Piggott H. Coccydynia: Retrospective review. J Bone Joint Surg 1981;63:635-6.

30. Wray CC, Easom S, Hoskinson J. Coccydynia. Aetiology and treatment. J Bone Joint Surg Br 1991;73(2):335-8. 